\begin{tabular}{l} 
JOURNAL OF EMPOWERMENT \\
VOL. 2, No. 2, Desember 2021, h. 172-182 \\
ISSN 2580-0620 (Print) \\
ISSN 2597-9809 (Online) \\
Available Online at https://jurnal.unsur.ac.id/index.php/JE \\
\hline \hline
\end{tabular}

\title{
PENGABDIAN KEPADA MASYARAKAT MELALUI KULIAH KERJA NYATA SEKOLAH TINGGI ILMU EKONOMI BIMA
}

\section{SERVICE TO THE COMMUNITY THROUGH REAL WORK OF SEKOLAH TINGGI ILMU EKONOMI BIMA}

\author{
Puii Muniarty', Wulandari², Aliah Pratiwi ${ }^{3}, M$ Rimawan 4 \\ 1234Sekolah Tinggi Ilmu Ekonomi (STIE) Bima \\ puji.stiebima@gmail.com,wulanbima.stiebima@gmail.com, \\ aliahpratiwi@ymail.com, rimawan111@gmail.com
}

\begin{tabular}{|l|l|l} 
Masuk : 09 Juli 2021 & Penerimaan : 06 Oktober 2021 & Publikasi : 31 Desember 2021
\end{tabular}

\begin{abstract}
ABSTRAK
Kuliah Kerja Nyata (KKN) merupakan sebuah bentuk intrakurikuler yang merupakan implementasi dari Tridharma Perguruan Tinggi memberikan pengalaman bekeria dan belajar mahasiswa dalam pemberdayaan masyarakat. Kegiatan kuliah kerja nyata menjadi peluang emas bagi mahasiswa yang cerdas, kritis, inovatif dan kreatif dalam mencarikan solusi, formulas dan strategi yang tepat untuk berbagai permasalahan unitunit usaha/UMKM yang tidak produktif dan pengembangan yang ada didesa. Penempatan lokasi mahasiswa KKN banyak diarahkan pada desa yang memiliki potensi yang unggul namun masih minim skill masyarakat dalam pengelolaan hasil alamnya. Ini menjadi tantangan tersendiri untuk kelompok peserta kuliah nyata untuk mengubah potensi unggul desa yang ada bernilai ekonomis melalui program kerja pemberdayaan masyarakat yang akan didampingi langsung oleh praktisi dan civitas akademika. Metode pengabdian masyarakat yand dilakuakan oleh mahasiswa KKN yaitu melalui pembekalan $\mathrm{KKN}$, penyuluhan dan pendampingan kewirausahaan, seminar edukasi dan sosialisasi Covid-19 dan evaluasi kegiatan KKN. Adapun sasarna dalam kegiatan ini yaitu masyarakat sekitar lokasi KKN yang terdiri atas ibu-ibu rumah tangga, personal pemilik usaha mikro dan anak-anak.
\end{abstract}

Kata Kunci : Kuliah; Masyarakat; Pemberdayaan; Pendidikan; Pengabdian.

\begin{abstract}
Real Work Lecture (KKN) is an intra-curricular form which is an implementation of the Tridharma of Higher Education to provide students with work and learning experiences in community empowerment. Real work lecture activities are a golden opportunity for smart, critical, innovative and creative students in finding the right solutions, formulas and strategies for various problems of unproductive business units/UMKM and development in the village. The placement of KKN student locations is mostly directed at villages that have superior potential but still lack community skills in managing their natural products. This is a challenge for the group of real lecture participants to change the existing superior potential of the village with economic value through community empowerment work programs that will be directly assisted by practitioners and the academic community. The community service method carried out by KKN students is through KKN debriefing, entrepreneurship counseling and mentoring, educational seminars and socialization of Covid-19 and evaluation of KKN activities. The target in this activity is the community around the KKN location consisting of housewives, personal micro business owners and children.
\end{abstract}

Keywords : Studying; Public; Empowerment; Education; Devotion.

\section{A. PENDAHULUAN}

Undang-Undang Republik Indonesia Nomor 12 Tahun 2012 Tentang Pendidikan Tinggi pada pasal 1 ayat 9 menyatakan bahwa Tridharma adalah kewajiban 
Perguruan Tinggi untuk menyelenggarakan Pendidikan, penelitian dan pengabdian kepada masyarakat, kemudian dijelaskan pula di ayat 11 bahwa pengabdian kepada masyarakat adalah kegiatan sivitas akademika yang memanfaatkan Ilmu Pengetahuan dan Teknologi untuk memajukan kesejahteraan masyarakat yang mencerdaskan kehidupan bangsa. Pada perguruan tinggi pelaksanaan pengabdian kepada masyarakat akan dilakukan oleh mahasiswa dalam bentuk Kuliah Kerja Nyata (KKN).

Pendidikan merupakan hal yang sangat penting bagi pembangunan manusia seutuhnya guna mencerdaskan dan meningkatkan kehidupan bangsa, (I Wayan Cong Sujana, 2019). Pendidikan dimaksud sebagai wadah untuk membina, mendidik, dan memajukan pola pikir bangsa Indonesia agar tumbuh dan berkembang menjadi manusia yang berilmu, disiplin, bertaqwa kepada Tuhan YME serta mempunyai dedikasi yang tinggi dalam melanjutkan cita-cita perjuangan bangsa, (Lazwardi, 2017). Tingkat kemajuan suatu bangsa salah satunya ditentukan oleh sumber daya manusia (SDM) yang berkualitas. Hal ini sangat dipengaruhi oleh tingkat partisipasi penduduk dalam hal pendidikan, penyedia sarana dan prasarana yang memadai. Dinamika masyarakat Indonesia saat ini jika dilihat dari perspektif pendidikan dalam masyarakat ada empat sumber masalah yaitu rendahnya kesadaran multicultural, penafsiran otonomi daerah yang lemah, kurangnya sifat kreatif dan produktif, rendahnya kesadaran moral dan hukum, (Sodik, 2020).

Kuliah Kerja Nyata (KKN) merupakan sebuah bentuk intrakurikuler yang merupakan implementasi dari Tridharma Perguruan Tinggi memberikan pengalaman bekerja dan belajar mahasiswa dalam pemberdayaan masyarakat (Syardiansah, 2017). Selain itu KKN sejatinya salah satu bentuk implementasi Tri Dharma Perguruan Tinggi yakni pengabdian. Namun KKN juga menjadi peluang implementasi Tri Dharma Perguruan Tinggi bentuk lainnya yakni pengajaran dan penelitian. Mahasiswa dituntut memiliki kreativitas dan perilaku inovatif guna memenuhi ketiga hal tersebut, (Umar, 2021). Kegiatan kuliah kerja nyata menjadi peluang emas bagi mahasiswa yang cerdas, kritis, inovatif dan kreatif dalam mencarikan solusi, formula dan strategi yang tepat untuk berbagai permasalahan unit-unit usaha/UMKM yang tidak produktif dan pengembangan yang ada di desa. Desa dapat dikatakan sebagai pemukiman manusia yang letaknya di luar kota dan penduduknya bermata pencaharian dengan bertani atau bercocok tanam. Dengan demikian, tidak heran beberapa penempatan lokasi kuliah kerja nyata banyak diarahkan pada desa yang memiliki potensi yang unggul namun masih minim skill masyarakat dalam pengelolaan hasil alamnya. Ini menjadi tantangan tersendiri untuk kelompok peserta kuliah nyata untuk mengubah potensi unggul desa yang ada bernilai ekonomis melalui program kerja pemberdayaan masyarakat yang akan didampingi langsung oleh praktisi dan civitas academica.

Sehubungan dengan ini, Sekolah Tinggi Ilmu Ekonomi (STIE) Bima melalui Lembaga Penelitian dan Pengabdian Kepada Masyarakat yang merupakan lembaga yang mengkoordinasi untuk meningkatkan kuantitas dan kualitas dan pengembangan teknologi dan pemberdayaan masyarakat dalam bentuk pelayanan dan kerja sama dengan masyarakat luas. Kuliah Kerja Nyata (KKN) Sekolah Tinggi Ilmu Ekonomi Bima Angkatan Ke-XVIII Tahun 2020 bersamaan dengan pandemi Covid-19 sehingga menyebabkan segala aktivitas dari pembekalan KKN yang diatur sesuai dengan kelompok per sheet waktu, selama pembekalan berlangsung mengikuti protap kesehatan yang telah ditetapkan dan selama pelaksanaan kegiatan dilapangan tetap mematuhi $5 \mathrm{M}$, optimalisasi 
pemberdayaan ekonomi mikro diera pandemic covid-19 serta menajamkan pemahaman warga terkait Covid- 19.

Oleh karena itu, sebelum mahasiswa dilepas ke lokasi maka dibekali dengan pembekalan Kuliah Keria Nyata yang dipandu langsung oleh pemateripemateri yang handal salah satunya yaitu materi KKN diera Covid-19 dan bagaimana bentuk-bentuk pemberdayaan masyarakat sehingga dapat mengubah mindset masyarakat yang lebih modern lagi dalam menghadapi persoalan-persoalan di zaman now dengan begitu diharapkan masyarakat peningkatan keterampilan masyarakat dan menumbuhkan jiwa wirausaha masyarakat. Menurut (Pardjono, 2005) pemberdayaan masyarakat melalui KKN meliputi: (1) Penyadaran yaitu KKN mampu mendorong dan menumbuhkan kesadaran akan potensi dan kemampuan yang dimiliki oleh masyarakat agar mampu meningkatkan kualitas kehidupan menuju kesejahteraan, menumbuhkan semangat untuk terus bekerja keras, dan memotivasi masyarakat agar mampu menumbuhkan keuanggulan, memiliki kemampuan untuk keluar dari tekanan hidup yang semakin berat. (2) Pembelajaran yaitu melalui proses pembelajaran yang berkesinambungan, mahasiswa bersama-sama masyarakat berupaya membentuk learning society (masyarakat pembelajar). Suatu masyarakat yang memiliki kesadaran untuk terus belajar membagi tugas dan tanggungjawab untuk menghantarkan generasi penerusnya mencapai kedewasaan dan memiliki jati diri yang mantap. Dengan demikian, generasi tersebut akan mampu mewujudkan masyarakat yang sejahtera. (3) pendampingan yaitu upaya ini dikerjakan agar masyarakat memiliki pasangan yang memiliki fungsi untuk mendampingi mereka dalam melaksanakan berbagai kegiatan dan berbagai upaya untuk meningkatkan keadilan dan kesejahteraan mitra dan atau masayarakat. Mahasiswa diharapkan memiliki kemampuan untuk mendampingi masyarakat sehingga mitra memiliki tingkat kepercayaan yang tinggi kepada mahasiswa. Jika kepercayaan telah diraih maka mahasiswa akan mampu melaksanakan program KKN sesuai dengan rancangan yang telah ditetapkan yang disesuaikan dengan masalah masyarakat dan kondisi diera covid-19.

Pengabdian yang dilakukan oleh (Gustina ef al., 2020) yang berjudul "Pemberdayaan Masyarakat Melalui Kegiatan Kuliah Kerja Nyata (KKN) Mahasiswa Universitas Bengkulu Periode 86 Tahun 2018 di Desa Tebat Monok Kabupaten Kepahiang" diperoleh hasil (1) Bentuk dalam proses perumusan isi program Kuliah Kerja Nyata (KKN) Mahasiswa Universitas Bengkulu Periode 86 Tahun 2018 di Desa Tebat Monok dilakukan dengan cara menyusun draft program kerja mahasiswa KKN melalui pertemuan lokakarya KKN; (2) Bentuk pelaksanaan pemberdayaan masyarakat yang dilakukan sebagai realisasi program kegiatan Kuliah Kerja Nyata (KKN) Mahasiswa Universitas Bengkulu Periode 86 Tahun 2018 di Desa Tebat Monok yaitu pelatihan inovasi produk dan sosialisasi teknik pengemasan serta labeling produk; (3) Hasil dari pemberdayaan masyarakat yang dilakukan melalui kegiatan Kuliah Kerja Nyata (KKN) Mahasiswa Universitas Bengkulu Periode 86 Tahun 2018 di Desa Tebat Monok yaitu terpenuhinya kebutuhan dasar masyarakat desa Tebat Monok di bidang kewirausahaan; dan (4) Peran Dosen Pembimbing Lapangan dalam kegiatan Kuliah Kerja Nyata (KKN) mahasiswa Universitas Bengkulu Periode 86 Tahun 2018 di Desa Tebat Monok yaitu Dosen Pembimbing Lapangan sudah menjalankan tugas dan fungsinya sesuai dengan ketentuan yang ada yaitu dengan mengadakan orientasi sampai pemberian nilai secara objektif. 
Tujuan pelaksanaan program kerja Kuliah Kerja Nyata (KKN) Tematik yang dilakukan oleh Mahasiswa Sekolah Tinggi llmu Ekonomi (STIE) Bima lebih diarahkan pada pemberdayaan masyarakat dengan pola pengelolaan sumber daya potensi desa yang ada pada masing-masing lokasi menjadi produk yang bernilai ekonomis, branding potensi desa melalui berbagai digital marketing, dan pelatihan, workshop dan penyuluhan, pendampingan yang dilakukan ke masyarakat tentang pemanfaatan potensi lokal desa yang kaya akan potensi perikanan, pertanian, peternakan, dan pariwisata sehingga mampu menciptakan sumber pendapatan baru yang dapat mieningkatkan taraf pendapatan masyarakat. untuk meningkatkan kemampuan dan ketrampilan sebagai sumber pendapan keluarga dan sosialisasi Covid-19.

\section{B. METODE}

Metode yang digunakan dalam pelaksanaan pengabdian kepada masyarakat melalui kuliah kerja nyata yang digunakan yaitu :

1. Observasi

Observasi merupakan metode yang digunakan oleh mahasiswa kuliah kerja nyata dengan datang ketempat lokasi pengabdian secara langsung, mahasiswa melakukan pendataan potensi desa dimasing-masing lokasi KKN.

2. Wawancara

Tahapan wawancara dilakukan dengan perangkat desa dan mitra terkait dengan masalah dan kendala yang ada didesa lokasi pengabdian kepada masyarakat yang dilakukan oleh masing-masing mahasiswa KKN. Mitra dari kegiatan ini adalah masyarakat yang ada dimasing-masing lokasi Kuliah Kerja Nyata STIE Bima dan kelompok usaha perorangan yang terdiri atas kelompok usaha tenun, kelompok usaha oi tua, kelompom usaha kerupuk ikan dan kelompok usaha tahu.

3. Pemanfaatan Teknologi

Pemanfaatan teknologi maksudnya disini adalah dari berbagai kegiatan yang dilaksanakan oleh mahasiswa kuliah kerja nyata dengan menggunakan berbagai media seperti media cetak online, youtobe, instagram dan sebagainya.

Lokasi KKN yang sudah ditentukan oleh Panitia Kuliah Kerja Nyata STIE Bima meliputi desa:

\begin{tabular}{|c|l|}
\hline Kelompok & \multicolumn{1}{|c|}{ Lokasi Kuliah Keria Nyata (KKN) } \\
\hline I. & Kecamatan Wawo Desa Maria \\
\hline II. & Kecamatan Palibelo Desa Ntonggu \\
\hline III. & Kecamatan Ambalawi Desa Nipa \\
\hline IV. & Kecamatan Soromandi Desa Bajo \\
\hline V. & Kecamatan Rasanae Timur Kelurahan Oimbo \\
\hline VI. & Kecamatan Raba Kelurahan Kendo \\
\hline VII. & Kecamatan Mpunda Kelurahan Panggi \\
\hline VIII. & Kecamatan Rasanae Barat Kelurahan Sarae \\
\hline \multicolumn{3}{|c|}{ Sumber data: Panitia KKN STIE Bima, 2020 } \\
\hline
\end{tabular}

Adapun tahap-tahap pelaksanaan pengabdian kepada masyarakat yang dilakukan sebagai berikut:

1. Persiapan

Pada tahapan ini akan dijelaskan langkah-langkah secara prosedural pelaksanaan KKN Tematik Tahun 2020 yang terdiri atas:

a. Tahap Pengumuman Dan Pendaftaran 
Dalam hal ini panitia Kuliah Keria Nyata (KKN) STIE Bima mengumumkan pembukaan pendaftaran KKN secara daring melalui link bit.ly/kknstiebima2020

b. Tahap Penyeleksian/ Validasi

Seleksi/ validasi pendaftaran dilakukan oleh Tim Panitian KKN secara offline. Pada tahap ini dilakukan verifikasi data dari berkas-berkas yang diupload mahasiswa dan bagi mahasiswa yang lolos verifikasi/validasi data dipindahkan ke Google Classroom sebagai calon peserta KKN untuk mengikuti proses-proses berikutnya.

c. Tahap Penetapan

TIM KKN akan menetapkan nama-nama mahsiswa calon peserta KKN untuk mengikuti pembekalan kkn dan mengambil lot penentuan lokasi KKN. Selain itu tim KKN menetapkan dosen pembimbing KKN melalui surat keputusan Ketua STIE Bima dan diberikan surat tugas untuk melaksanakan KKN Tematik.

d. Tahap Pelaksanaan

1) Aktivitas $K K N$ tematik terdiri dari pembekalan, kegiatan lapangan dan pelaporan yang harus diselesaikan selama \pm 1 bulan.

2) Kegiatan KKN bisa dilaksanakan secara daring, luring atau gabungan dari daring dan luring (hibrid).

3) KKN tematik dibimbing oleh 2 orang Dosen Pembimbing KKN.

4) KKN tematik dilakukan secara berkelompok dan bekeria sama dengan pemerintah desa yang dilaksanakan di desa/kelurahan.

5) Tahap monev. Tim panitia KKN melakukan monitoring dan evaluasi pelaksanaan KKN melalui bidang monitoring dan evaluasi pelaksanaan $\mathrm{KKN}$. Bidang monitoring dan evaluasi membuat laporan hasil pelaksanaan Kuliah Keria Nyata kepada Ketua panitia KKN STIE Bima. Ketua KKN STIE Bima kemudian menjadikan hasil evaluasi sebagai umpan balik untuk peningkatan penjaminan mutu yang berkelanjutan.

6) Tahap pelaporan. (1) Dosen pembimbing memberikan penilaian mahasiswa peserta KKN Tematik berdasarkan ketentuan yang telah diinformasikan oleh panitia KKN. Hasil penilaian mahasiswa ini akan dikirim ke program studi untuk dicatat dalam nilai mahasiswa peserta KKN dan (2) Ketua panitia KKN Tematik wajib menyerahkan laporan pelaksanaan kegiatan KKN kepada Ketua STIE Bima.

\section{Pelaksanaan}

Adapun beberapa metode pengabdian kepada masyarakat dalam bentuk pemgabdian masyarakat yang diakukan oleh peserta KKN Tematik STIE BIMA tahun 2020:

a. Sosialisasi program kerja Kuliah Kerja Nyata (KKN). Sosialisasi ini bertujuan untuk menginformasikan program kerja KKN kepada masyarakat baik berupa program kerja utama dan program kerja penunjang.

b. Penyuluhan dan pendampingan tentang kewirausahaan. Penyuluhan ini dilakukan di balai desa dan atau kantor desa karena masih banyak masyarakat yang berada dilokasi Kuliah Kerja Nyata masih minim tentang ilmu pengetahuan kewirausahaan. Dalam hal ini, mitra diberikan teori dan bentuk-bentuk edukasi pengelolaan potensi lokal desa yang ada dan materi ekonomi konvensional dan modern sehingga mitra dapat berkolaborasi secara internal maupun eksternal terkait bisnis atau usaha. Tujuan penyuluhan dan pendampingan ini adalah untuk mendampingi mitra dalam 
pengolahan potensi desa, manajemen usaha dan media promosi produk yang dihasilkan melalui berbagai platform digital marketing. Selain itu, program ini juga memberikan ilmu dan wawasan baru kepada mitra tentang wirausaha dan peluang usaha berbasis rumahan sehingga terbuka pikiran serta tumbuh minat dan motivasi dalam diri. mereka untuk berwirausaha. Di samping itu, juga diberikan materi tentang prinsip dasar pembuatan, pengemasan dan pemasaran produk, bertujuan agar mitra mengetahui cara pembuatan, pengemasan yang baik dan strategi pemasaran produk. Penyuluhan ini disampaikan dalam bentuk ceramah, tanya jawab dan diskusi.

c. Seminar Edukasi dan Sosialisasi Covid-19. Kegiatan inl dilaksanakan karena saat ini jumlah penderita Covid-19 cukup tinggi sehingga pemerintah membuat kebijakan sebagai langkah pertama yaitu berupa anjuran social distancing. Oleh karena itu, pemerintah menganjurkan kepada siapapun untuk tetap mematuhi $3 M$ tujuannya untuk membatasi penularan Covid-19. Dalam kegiatan ini bertujuan untuk memberikan informasi kepada masyarakat tentang edukasi penyebaran Covid-19 sehingga mereka lebih paham dan mengerti untuk mencegah, menghadapi, dan menangani kasus Covid-19 yang sampai saat ini kasusnya semakin meningkat secara signifikan.

d. Edukasi trauma healing. Kegiatan ini dilakukan kepada anak-anak korban kebakaran. Bukan saja dampak secara fisik tetapi juga membuat dampak psikis yang masih membekas bagi sebagian korban bencana kebakaran. Kegiatan tersebut menjadi titik fokus untuk membantu mengurangi trauma yang dialami sebagaian korban bencana.

e. Evaluasi. Evaluasi kegiatan dilakukan setelah serangkaian tahap pelaksanaan untuk mengukur keberhasilan kegiatan pengabdian kepada masyarakat dimana mitra akan memberikan masukan maupun saran terhadap kegiatan program kerja Kuliah Kerja Nyata.

3. Monitoring

Bentuk monev yang dilakukan oleh panitia bagi pelaksanaan KKN yaitu pada tahun 2021 STIE Bima melakukan gebyar Wirausaha Season I sebagai pameran potensi lokal dan bazar produk hasil pengabdian masyarakat yang dilakukan oleh mahasiswa KKN Angkatan Ke-XVIII tahun 2020 yang dapat diakses melalui https://kahaba.net/berita-kota-bima/87547/stie-bima-gelar-gebyar-wirausahamahasiswa-mahasiswi-unjuk-kemampuan.html

\section{HASIL ATAU PEMBAHASAN}

Pelaksanaan kegiatan KKN-Tematik dalam bentuk pemberdayaan masyarakat merupakan hal penting dilakukan tentunya ini perlu persiapan dan pembekalan yang matang dari panitia dan dosen pembimbing sehingga akan memudahkan mahasiswa dalam memahami teknis pelaksanaan di lapangan. Pembekalan KKN dilaksanakan selama 3 hari dan wajib diikuti oleh semua peserta KKN-Tematik yang dinyatakan telah lolos verifikasi data pendaftaran. Materi pembekalan KKN terdiri atas (1) Gambaran umum Kuliah Kerja Nyata, (2) Pemberdayaan Masyarakat, (3) Kuliah Keria Nyata Dimasa Covid-19 dan (4) Adminitrasi dan Pelaporan Kuliah Kerja Nyata. 


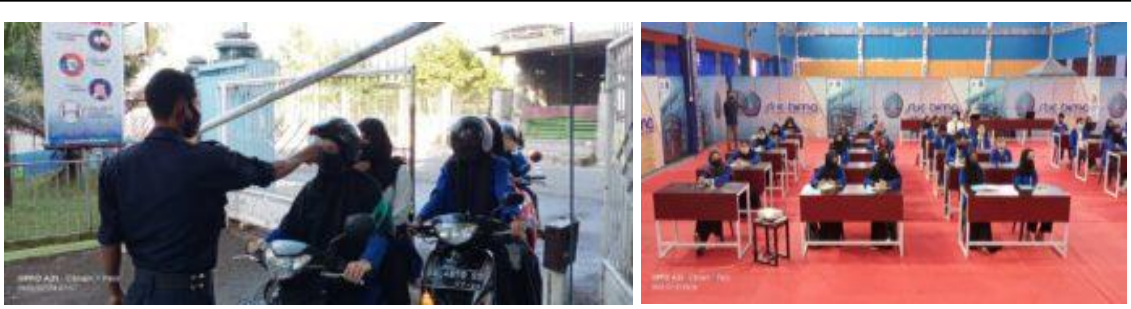

Gambar 1. Standar Protap Kesehatan Covid-19 Selama Pembekalan KKN

Selama pelaksanaan pembekalan dilaksanakan mahasiswa tetap mematuhi standar covid-19 yang telah ditetapkan oleh pemerintah. Adapun standar yang dimaksud seperti harus tetap mengenakan masker, menjaga jarak, tidak bersentuhan dan lain-lain. Misalnya dipintu masuk kampus, sudah ada petugas yang mengecek suhu badan, jika diatas normal akan dipulangkan. Begitupun dengan wadah cuci tangan dengan sabun sudah disiapkan disejumlah titik.
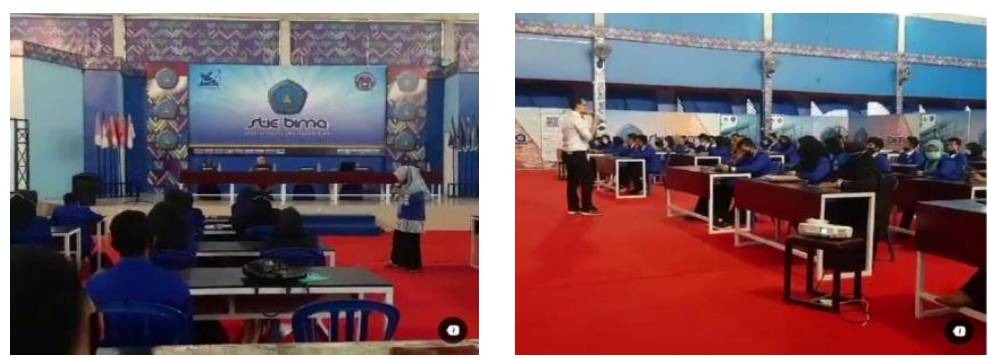

Gambar 2. Pemateri Pembekalan Kuliah Keria Nyata

Mater-materi yang disampaikan oleh masing-masing narasumber mendapat respon yang cukup tinggi dari peserta pembekalan Kuliah Keria Nyata hal ini ditandai karena setiap sesi akhir materi beberapa mahasiswa bertanya hal-hal yang menjadi kegiatan selama dilokasi kuliah kerja nyata dimasing-masing desa yang telah ditentukan panitia KKN. Dengan materi pembekalan ini diharapkan mahasiswa untuk dapat mengimplementasikan iptek yang pernah didapat selama dibangku kepada masyarakat.

Setelah diberikan pembekalan maka mahasiswa dilepas ke lokasi oleh Ketua Sekolah Tinggi Ilmu Ekonomi (STIE) Bima secara resmi melalui prosesi acara pelepasan mahasiswa Kuliah Kerja Nyata (KKN) Angkatan Ke-XVIII Tahun 2020 di Auditorium STIE Bima. Pelepasan peserta KKN-Tematik menandakan bahwa peserta KKN sudah siap mengamalkan ilmu pengetahuan yang sudah didapatkan selama dibangku kuliah untuk diimplementasikan ke masyrakat. Hal ini dapat memberikan efek yang positif bagi mahasiswa karena dengan begitu mahasiswa dapat mengetahui langsung permasalahan real di lapangan dan memberikan solusi yang terbaik dengan kendala yang terjadi selama temuan dilokasi KKN. Pelepasan peserta KKN disambut dengan antusias oleh mahasiswa karena ini merupakan langkah awal mengkombaikan antara teori dan praktek dilapangan secara efektif dan efisien serta memberikan nilai manfaat langsung kepada masyarakat. 


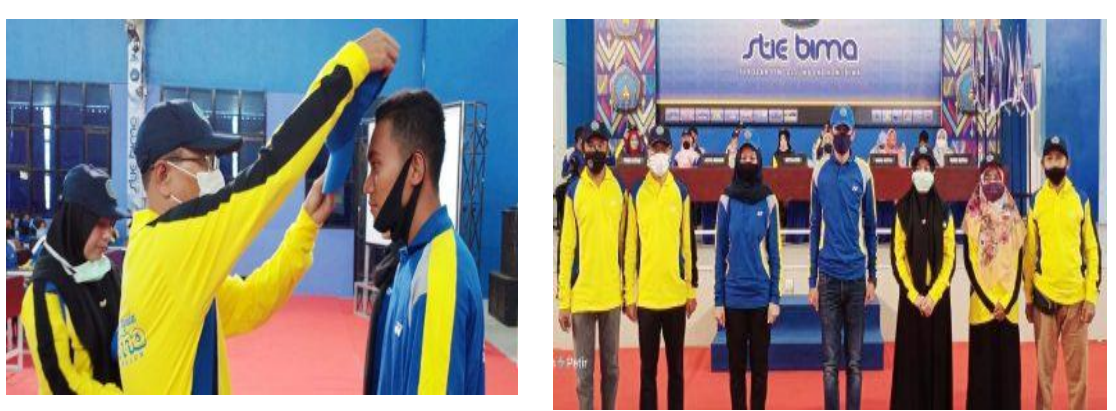

Gambar 3. Pelepasan Mahasiswa Kuliah Kerja Nyata

Setelah peserta KKN berada di lokasi maka mereka secara tidak langsung melakukan identifikasi dan pendataan potensi desa dan permasalahan mitra lalu melakukan rapat guna mendiskusikan jenis program kerja yang akan dilaksanakan selama kegiatan Kuliah Kerja Nyata (KKN). Kemudian program kerja yang telah disepakati bersama akan di sosialisasikan di tingkat kelurahan/desa. Dalam sosialisasi tersebut dilakukan pemaparan materi yang berisikan program pelaksanaan, bentuk kegiatan dan sasaran masing-masing program, respon masyarakat sangat tinggi dengan progran kerja KKN.

Kuliah Kerja Nyata (KKN) tujuan utamanya melaksanakan salah satu Tridharma Perguruan Tinggi yaitu pengabdian pada masyarakat. KKN pun bertujuan membangun citra sekolah tinggi dalam rangka membina dan mensejahterakan desa dan masyarakat dengan berbagai program-program yang dibawa oleh mahasiswa dan harus diimplementasikan. Adapun program yang dilaksanakan oleh mahasiswa selama melaksanakan Kuliah Kerja Nyata :

1. Penyuluhan dan pendampingan kewirausahaan. Penyuluhan ini dilaksanakan di aula desa mempresentasikan berbagai produk yang telah dihasilkan oleh peserta KKN kepada masyarakat. produk-produk yang dikenalkan adalah produk yang merupakan hasil olahan potensi lokal yang ada di lokasi KKN. Dengan melihat potensi lokal memberikan ide kreatif untuk menciptakan produk baru yang lebih bernilai ekonomis sehingga diharapkan dapat membantu meningkatkan ekonomi masyarakat. Acara penyuluhan ini mendapat tanggapan yang positif dari berbagai pihak salah satunya dari kepala lurah/desa karena selama ini masyarakat setempat belum paham dan minim akan pengolahan lebih kanjut dengan hasil potensi desa yang ada. Melalui penyuluhan ini diharapkan masyarakat dapat memahami tentang bagaimana cara memanfaatkan sumber daya yang ada bisa dikelola dan dimanfaatkan serta dijadikan usaha serta menjadi daya tarik masyarakat luar terhadap hasil produksi masyarakat dimasing-masing lokasi Kuliah Kerja Nyata (KKN) STIE Bima Angkatan ke-XVIII Tahun 2020. Dengan adanya penyuluhan ini mitra juga mengetahui peluang-peluang usaha yang bisa dikembangkan di daerah setempat sehingga desa/kelurahan dapat menjadi desa mandiri dan menambah wawasan masyarakat dalam pengelolaan kewirausahaan dalam rangka meningkatkan ekonomi masyarakat. 


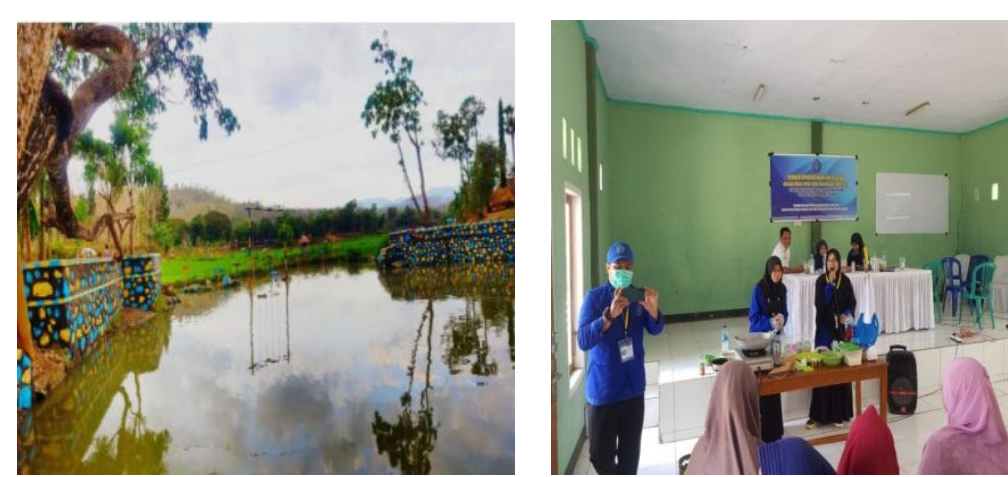

Gambar 4. Penyuluhan dan pendampingan kewirausahaan

2. Seminar Edukasi dan Sosialisasi Covid-19 ini bertujuan untuk memberikan pemahaman, kepatuhan dan kesadaran masyarakat tentang protokoler kesehatan untuk mengurangi resiko penularan penyakit Covid-19. Tujuan ini tidak lepas dari teori konsep Law is a tool of social enginering dari Roscoe Pound yang menyatakan bahwa hukum atau aturan yang dibuat oleh penguasa akan mengubah perilaku masyarakat untuk mematuhi hukum tersebut. Hal ini termasuk pada protokol kesehatan yang sebenarnya merupakan upaya strategi dan kebijakan pemerintah untuk mencegah penularan penyakit Covid-19 yang berusaha untuk mengubah perilaku kebiasan masyarakat melalui $5 \mathrm{M}$ yaitu mencuci tangan, menjaga jarak, memakai masker, mengurangi mobilitas dan menghindari kerumunan. kegiatan sosialisasi mendapat sambutan yang sangat positif dari masyarakat, masyarakat juga sangat membutuhkan informasi yang jelas dan benar terkait Covid-19. Selepas dari pelaksanaan seminar edukasi dan sosialisasi covid-19, mahasiswa KKN melanjutkan dengan pembagian masker kepada masyarakat kelurahan Oimbo yang terpusatkan di beberapa titik keramaian.
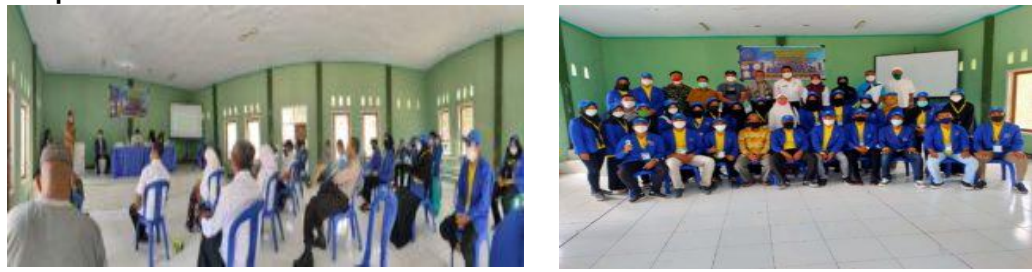

Gambar 5. Seminar Edukasi Dan Sosialisasi Covid-19

3. Edukasi trauma healing yang dilakukan mahasiswa KKN berupaya memberikan bantuan trauma healing kepada korban bencana kebakaran dengan bertindak sebagai mentor memmberikan edukasi kepada anakanak korban kebakaran yaitu dengan melaksanakan pola belajar sambil bermain dan memberikan pelajaran saat tatap muka bersama disaat guru ditiadakan. Pemulihan trauma anak-anak bukanlah hal yang instan namun dengan adanya trauma haedling anak-anak dapat menyuarakan perasaan dan harapan apa yang menjadi hal-hal yang mereka tidak sukai dan yang disukai dengan harapan dapat menghilangkan trauma akibat insiden kebakaran. 


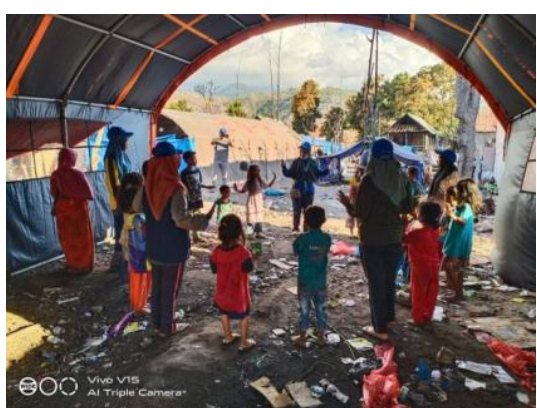

Gambar 6. Kegiatan Trauma Headling Bagi Anak-anak Korban Kebakaran di Ntonggu

\section{PENUTUP}

1. Kesimpulan

Berasarkan hasil kegiatan pemberdayaan kepada masyarakat, dapat dikemukakan beberapa kesimpulan sebagai berikut :

a. Ketrampilan dalam pemberdayaan usaha ekonomi produktif memberikan peluang dan manfaat bagi masyarakat untuk mengelola dan mengembangkan sumber daya potensi lokal yang ada guna meningkatkan wawasan dan keterampilan masyarakat dalam menginovasi sumber daya yang ada sehingga bernilai ekonomis dan sebagai sumber pendapatan baru mitra.

b. Bagi mahasiswa Kuliah Kerja Nyata (KKN) dapat melatih dan mengembangkan kemampuan soft skills dan hard skills mahasiswa dalam menyelesaikan masalah-masalah sosial dan ekonomi masyarakat. Dari demo produk disaat penuyuluhan dan pendampingan kewirausahaan masyarakat mengetahui cara mempromosikan produk melalui media sosial dan edukasi wisata serta bahaya dan cara pencegahan covid-19.

c. Bagi anak-anak korban trauma kebakaran merasa terbantu dalam menghilangkan trauma yang dialami hal ini ditandai bangkit kembalinya semangat anak-anak korban kebakaran untuk belajar lagi seperti sedia kala walapun masih ada beberapa fasilitas yang belum memadai.

\section{Saran}

Rekomendasi untuk mahasiswa KKN berikutnya untuk lebih menggali dan mengidentifikasi potensi desa sehingga pengabdian kepada masyarakat melalui KKN dalam bentuk pemberdayaan msayarakat lebih berinovasi dan kreatif sesuai dengan kondisi generasi milenial dan menciptakan entrepreneur yang cerdas dan kritis dalam mengelola sumber daya yang ada.

\section{E. UCAPAN TERIMA KASIH.}

Penulis mengucapkan terima kasih kepada Sekolah Tinggi llmu Ekonomi (STIE) Bima selaku penyelenggara Kuliah Kerja Nyata (KKN) tahun 2020 dan semua pihak yang terlibat didalam pengabdian kepada masyarakat melalui KKN sehingga setiap kegiatan berjalan dengan lancar dan aman.

\section{F. DAFTAR PUSTAKA.}

Aliyyah, R. R., Septriyani, W., Safitri, J., Nur, S., \& Ramadhan, P. (2021). KULIAH KERJA NYATA : PENGABDIAN KEPADA MASYARAKAT. 5(2), 663-676.

Basuki, K. (2019). Peranan Kuliah Kerja Ny. ISSN 2502-3632 (Online) ISSN 2356-0304 (Paper) Jurnal Online Internasional \& Nasional Vol. 7 No.1, Januari - Juni 2019 Universitas 17 Agustus 1945 Jakarta, 53(9), 1689-1699. 
Gustina, D., Adbullah, I., \& Sofino, S. (2020). Pemberdayaan Masyarakat Melalui Kegiatan Kuliah Kerja Nyata (Kkn) Mahasiswa Universitas Bengkulu Periode 86 Tahun 2018 Di Desa Tebat Monok Kabupaten Kepahiang. Journal Of Lifelong Learning, 2(1), 35-39.

Haeruddin, M. I. M., Abdul Hakim, Muhammad Ichwan Musa, Agung Widhi Kurniawan, Abdi Akbar, Uhud Darmawan Natsir, \& M. Ilham Wardhana Haeruddin. (2020). Pemberdayaan Usaha Ekonomi Produktif bagi Masyarakat di Kelurahan Allepolea, Kecamatan Lau Kabupaten Maros. JURPIKAT (Jurnal Pengabdian Kepada Masyarakat), 1(2), 83-93.

Hafizha, A. L., Safitri, E. N., Mukaromah, L., Afidda, M. N., \& Sukma, S. I. (2019). Edukasi Covid-19 Guna Mencegah Penularan Covid-19. Pendidikan, Jurusan Dasar, Sekolah Pendidikan, Fakultas Ilmu Manajemen, Jurusan Ekonomi, Fakultas, 1-8.

Lazwardi, D. (2017). Manajemen Kurikulum Sebagai Pengembangan Tujuan Pendidikan. Idarah : Jurnal Pendidikan Islam, 7(1), 99-1 12.

Pardjono. (2005). "Program Pemberdayaan Masyarakat". Kumpulan Modul Pembekalan Kuliah Kerja Nyata Universitas Negeri Yogyakarta. LPM UNY.

Rachmadi, T. R., Wakhid Yuliyanto, Nurhayatun, \& Ari Waluyo. (2021). Pemberdayaan Masyarakat Dalam Pencegahan Penularan COVID-19 Melalui Sosialisasi Protokol Kesehatan di Pasar Rantewringin, Kecamatan Buluspesantren, Kabupaten Kebumen. JURPIKAT (Jurnal Pengabdian Kepada Masyarakat), 2(1), 126-136.

Sodik, F. (2020). Pendidikan Toleransi Dan Relevansinya Dengan Dinamika Sosial Masyarakat Indonesia. Tsamratul Fikri, 14(1), 1-14.

Sujana Cong I Wayan. (2019). Fungsi Dan Tujuan Pendidikan Indonesia. ADI WIDYA Jurnal Pendidikan Dasar, 4(1), 29-39.

Sujana, I. W. C. (2019). Fungsi Dan Tujuan Pendidikan Indonesia. Adi Widya: Jurnal Pendidikan Dasar, 4(1), 29. https://doi.org/10.25078/aw.v4i1.927

Syardiansah. (2017). PENGEMBANGAN KOMPETENSI MAHASISWA ( Studi Kasus Mahasiswa Universitas Samudra KKN Tahun 2017 ). Jim Upb, 7(1), 57-68. 